\title{
The importance of endothelin-I for microvascular dysfunction in diabetes
}

\author{
Majid Kalani \\ Department of Clinical Sciences \\ Karolinska Institutet, \\ Dept of Cardiology, Danderyd \\ Hospital, Stockholm, Sweden
}

\begin{abstract}
Most of the late diabetic complications such as retinopathy, nephropathy, and neuropathy, have their basis in disturbed microvascular function. Structural and functional changes in the microcirculation are present in diabetes mellitus irrespective of the organ studied, and the pathogenesis is complex. Endothelial dysfunction, characterized by an imbalance between endothelium-derived vasodilator and vasoconstrictor substances, plays an important role in the pathogenesis of diabetic microangiopathy. Increased circulating levels of endothelin-1 (ET-1), a potent vasoconstrictor peptide, has been found in patients with diabetes, and a positive correlation between plasma ET-1 levels and microangiopathy in patients with type 2 diabetes has been demonstrated. In addition to its direct vasoconstrictor effects, enhanced levels of ET-1 may contribute to endothelial dysfunction through inhibitory effects on nitric oxide (NO) production. Vascular endothelial dysfunction may precede insulin resistance, although the feature of insulin resistance syndrome includes factors that have negative effects on endothelial function. Furthermore, ET-1 induces a reduction in insulin sensitivity and may take part in the development of the metabolic syndrome. In the following, the mechanisms by which ET-1 contributes to the development of diabetic microangiopathy and the potentially beneficial effect of selective $\mathrm{ET}_{\mathrm{A}}$ receptor antagonists are discussed.
\end{abstract}

Keywords: endothelin-1, diabetes mellitus, microcirculation, diabetic microangiopathy, $\mathrm{ET}_{\mathrm{A}}$-receptor antagonist

\section{Introduction}

Incidence and prevalence rates of type 2 diabetes are rising in most countries (King et al 1998). Diabetes mellitus is associated with an increased risk of cardiovascular diseases related to both macro- and microangiopathy, eg, myocardial infarction, peripheral arterial occlusive disease, stroke, retino-, neuro-, and nephropathies, causing considerable disability and premature death in individuals with diabetes. Diabetic skin microangiopathy contributes to the development of chronic foot ulcers, a common and severe complication often leading to major disability and increased mortality and also frequently resulting in amputation of the leg (Jeffcoate et al 2003). Endothelium-dependent vasodilation is impaired in the skin microcirculation of patients with type 2 diabetes (Caballero et al 1999). Furthermore, autonomic neuropathy may cause increased shunting of blood through arteriovenous anastomoses and lead to impaired circulation through nutritive capillaries (Boulton et al 1982; Fagrell et al 1999; Tooke 2000). Endothelial dysfunction, characterized by an imbalance between endothelium-derived vasodilator and vasoconstrictor substances, plays an important role in the pathogenesis of vascular complications in diabetes, including microangiopathy (Tooke 1995; Creager et al 2003; Luscher et al 2003).

\section{Diabetic microangiopathy}

The microcirculation comprises the arterioles, capillaries, venules, and lymphatics, all $<100 \mu \mathrm{m}$ in diameter. These vessels are crucial for maintaining tissue metabolism. 
Structural and functional changes in the microcirculation are present in diabetes mellitus irrespective of the organ studied. We have shown that functional disturbances in the skin microcirculation of the fingers are present three years after the onset of type 1 diabetes, and the majority of the patients have developed disturbances after 7-12 years (Kalani et al pers comm). The pathophysiology of diabetic microangiopathy is complex in that it involves not only metabolic, but also genetic factors. Subjects with diabetes heredity show impaired microvascular responses to both endothelium- and nonendothelium-dependent stimuli in the skin microcirculation in spite of normal body dimensions, normal glucose tolerance, and normal insulin sensitivity (Jörneskog et al 2005). Early on in the course of the disease, microvascular perfusion is increased in many organs under resting conditions (Tooke 1983, 1986). A cutaneous microvascular overperfusion occurs in the limbs, but most of the blood flow under normal thermal conditions passes through arteriovenous shunts, bypassing the nutritive capillary bed and leading to so-called "capillary ischemia" (Boulton et al 1982; Tooke 1983; Fagrell et al 1999). Increased skin microvascular perfusion has been shown to be related to poor glycemic control (Gundersen et al 1974; Tymms et al 1988; Jörneskog et al 1998). It should be pointed out that the early microvascular hyperemia occurs only under resting conditions, while under conditions that stress the microcirculation, eg, tissue injury or a period of arterial occlusion, a limited hyperemic response is observed (Rayman et al 1986; Walmsley et al 1989; Sandeman et al 1991). This has been clearly demonstrated by investigations of the nutritive skin capillary flow (capillary blood cell velocity; $\mathrm{CBV}$ ) in diabetic feet using videophotometric capillaroscopy, along with measurements of the total skin microcirculation by laser Doppler fluxmetry (LDF), demonstrating reduced skin capillary hyperemia in terms of the post-occlusive peak value obtained and the time taken to reach peak flow (Walmsley et al 1989; Tur et al 1991; Jörneskog 1995).

There are, however, probably differences in the pathogenesis of microangiopathy between type 1 and type 2 diabetes. In type 2 diabetes, there is a complex interaction between impaired insulin sensitivity, vascular endothelial dysfunction, and hypertension, which seems to play an important role in the development of functional disturbances in the microcirculation. Impaired insulin sensitivity is associated with a modification of arterial resistance and increased peripheral microvascular resistance, which contributes to the excessive prevalence of hypertension in type 2 diabetes.
In these patients, an increased peripheral microvascular resistance occurs with even minor degrees of impaired glucose tolerance, which coexists with disturbed capillary pressure autoregulation, leading to the development of irreversible structural changes in the microvasculature (Gall et al 1991; Jaap et al 1994; Shore et al 1994).

\section{Endothelin-I}

Endothelin-1 (ET-1) is the principal cardiovascular isoform of the endothelin system (Yanagisawa et al 1988). Vascular ET-1 is produced primarily in the endothelium, although it can also be produced in vascular smooth muscle cells (VSMC), macrophages, leukocytes, cardiomyocytes, and fibroblasts (Resink et al 1990; Properzi et al 1995). In the kidney, tubular epithelial cells, mesangial cell, and podocytes are capable of ET-1 release (Kohan 1997). Several mechanisms are involved in the clearance of ET-1 from plasma, including endocytosis in the lungs, enzymatic degradation, degradation of the endothelin B-receptor-ligand complex, and enzymatic processes in the kidney and liver (Anggard et al 1989; Abassi et al 1992; Johnström et al 2005). Two receptor subtypes, endothelin A- and B-receptors $\left(\mathrm{ET}_{\mathrm{A}}\right.$ and $\left.\mathrm{ET}_{\mathrm{B}}\right)$, mediate the effects of ET-1. Vascular smooth muscle cells express both $\mathrm{ET}_{\mathrm{A}}$ and $\mathrm{ET}_{\mathrm{B}}$, while endothelial cells express primarily $\mathrm{ET}_{\mathrm{B}}$ (Molenaar et al 1993). On smooth muscle cells, $\mathrm{ET}_{\mathrm{A}}$ mediates vasoconstriction and mitogenesis, while $\mathrm{ET}_{\mathrm{B}}$ receptor has a dual function and has been shown to cause both vasoconstriction and vasodilation (Sakurai et al 1992; Seo et al 1994). $\mathrm{ET}_{\mathrm{A}}$ receptor activation contributes to coronary constrictor tone and peripheral and coronary endothelial dysfunction (Kyriakides et al 2000; Halcox et al 2001). In isolated human internal mammary and porcine coronary arteries, $\mathrm{ET}_{\mathrm{B}}$ receptor mediates ET-1-induced vasoconstriction (Seo et al 1994). In healthy humans, selective $\mathrm{ET}_{\mathrm{B}}$ receptor antagonism increases peripheral vascular resistance, which means that vasodilation is the favored $\mathrm{ET}_{\mathrm{B}}$ pathway (Strachan et al 1999). However, the balance between vasodilator and vasoconstrictor $\mathrm{ET}_{\mathrm{B}}$ pathways may be altered in pathological conditions (Cardillo et al 1999; Pernow et al 2000).

ET-1 is one of the most potent vasoconstrictors described and has been suggested to be involved in the development of cardiovascular disease. ET-1 also has proinflammatory and profibrotic effects, which may contribute to the pathogenesis of cardiovascular disease. Endogenous ET-1 is important for maintaining vascular tone, and enhanced endogenous ET-1 has been demonstrated in hypertension, coronary artery disease, and heart failure 
(Cardillo et al 1999, 2000; Cowburn et al 1999; Love et al 2000; Nohria et al 2003).

\section{The role of endothelin-I in diabetic microangiopathy}

The pathophysiology of diabetic microangiopathy is complex and many important aspects of it still are not fully understood. The major microvascular complications of diabetes are nephropathy, retinopathy, neuropathy, and skin microangiopathy. Both metabolic and hemodynamic factors contribute to the development of diabetic microvascular complications (Cooper 1998; Groop et al 2005), which, in spite of similar final clinical manifestations in both type of diabetes, probably have different pathophysiological pathways regarding the organ and/or complication studied. In type 2 diabetes, endothelial dysfunction is an early feature of the disease, linking cardiovascular risk factors and insulin resistance in different pathways to clinically manifest cardiovascular complications (Jansson 2007; Rask-Madsen et al 2007). The vascular endothelium maintains vascular tone and has important hemostatic function, and endothelial dysfunction is of major importance in the pathogenesis of atherosclerosis and diabetic angiopathy (Tooke et al 2000; Rask-Madsen et al 2007). Several studies support the hypothesis that endothelial dysfunction is a precursor of type 2 diabetes, indicating that vascular endothelial dysfunction may precede insulin resistance, although the features of insulin resistance syndrome include factors that have negative effects on endothelial function (Tooke et al 2000; Groop et al 2005; Jansson 2007; Rask-Madsen et al 2007). Impaired endothelial-dependent and independent microvascular reactivity has also been demonstrated in healthy subjects with risk factors for type 2 diabetes (Caballero et al 1999; Jörneskog et al 2005). One important feature of endothelial dysfunction is an increased production and biological activity of the potent vasoconstrictor and proinflammatory peptide ET-1. Elevated levels of ET-1 are found in patients with type 2 diabetes (Takahashi et al 1990; Verhaar et al 1998; Mather et al 2002), and ET-1-induced reduction in insulin sensitivity may take part in the development of the metabolic syndrome (Ahlborg et al 2002). In diabetes mellitus, a primary disturbance in ET-1 production from vascular endothelium exists as an early phenomenon rather than a result of advanced stage of the disease (Donatelli et al 1994; Anfossi et al 2007).

Furthermore, ET-1 may contribute to the development of endothelial dysfunction, and consequently insulin resistance, by increasing the production of reactive oxygen species, mainly superoxide anion, in the vasculature. This is mainly dependent upon the activation of NADPH oxidase protein expression and activity (Wedgwood et al 2001; Li et al 2003; Romero et al 2008).

\section{Diabetic nephropathy}

ET-1 is secreted by glomerular endothelial cells, mesangial cells, and epithelial cells. Activation of endothelin receptors in the kidney leads to constriction of renal vessels, inhibition of salt and water reabsorption, and enhanced glomerular proliferation. Alterations in ET-1, at both mRNA and receptor levels are seen in animal models of diabetes. Several human studies show a correlation between plasma or urinary levels of ET-1 and signs of diabetic nephropathy at different stages in terms of an increased glomerular filtration rate, mesangial expansion, macro- and/or microalbuminuria, and uremia (Lee et al 1994; De Mattia et al 1998; Ak et al 2001; Candido et al 2002; Zanatta et al 2008). However, most of the interventional studies on selective or dual endothelin receptor blockers have been done in animal models with encouraging results (Chade et al 2006; Sasser et al 2007).

\section{Diabetic neuropathy}

Diabetic neuropathy is one of the most frequent and expensive complications of diabetes. The peripheral sensorimotor and autonomic neuropathies play an important role in the pathogenesis of diabetic foot ulceration. Sympathetic neuropathy also results in arteriovenous shunting, leading to impaired blood flow through nutritive capillaries. Both hemodynamic and metabolic factors contribute to the development of diabetic neuropathy. Microvascular dysfunction is seen at an early stage in the peripheral nerve, which contributes to impaired endoneurial blood flow, leading to destruction of neuronal and Schwann cells and, finally, nerve degeneration (Low et al 1989; Cameron et al 1991, 1995). In patients with diabetes, endoneurial microangiopathy, and in particular basement membrane thickening, is related to clinical and neurophysiological measures of neuropathy. Endoneurial capillary microangiopathy presages deterioration in glucose tolerance and seems to be an early and persistent feature in the processes underlying diabetic peripheral neuropathy (Thrainsdottir et al 2003). Interestingly, diabetic patients without evidence of neuropathy demonstrate endoneurial microangiopathy. Microangiopathy may therefore precede the development of peripheral neuropathy (Giannini et al 1995).

ET-1 contributes to endothelial abnormalities and the altered balance of vasodilation and vasoconstriction in favor of the latter in diabetes. Furthermore, endothelin receptors are expressed in neurons and glial cells and are probably involved 
in the transduction of nociceptive information (Gokin et al 2001). $\mathrm{ET}_{\mathrm{A}}$ receptor blockade attenuates tactile allodynia in the streptozotocin-induced diabetic rat, suggesting that $\mathrm{ET}_{\mathrm{A}}$ receptors may contribute to the development of peripheral neuropathy in experimental diabetes (Jarvis et al 2000). Interestingly, a protective role for $\mathrm{ET}_{\mathrm{B}}$ receptors following neuronal injury has been described (Siren et al 2002; BertiMattera et al 2006).

\section{Diabetic retinopathy}

Diabetic retinopathy is a potentially sight-threatening complication that develops in nearly all patients with diabetes. Ocular tissues, eg, vascular and extravascular sites in the retina are a rich source of ET-1 expression, and ET-1 contributes to abnormal retinal hemodynamics in diabetic retinopathy (Kohner et al 1995; Pang et al 1997). Results from several studies in streptozotocin-induced diabetic rats have suggested a role of ET-1 in the pathogenesis of diabetic retinopathy (Chakrabarti et al 1997, 1998). An interaction between ET-1 and vascular endothelial growth factor (VEGF) has also been reported, and some positive results of treatment with endothelin receptor blockers have raised interest in these substances as potentially therapeutic agents (Masuzawa et al 2006). However, most of the studies on the role of ET-1 in the pathogenesis of diabetic retinopathy and the importance of endothelin blockers in the treatment of this serious complication have been done in animal models. There is, however, sufficient evidence that strongly links ET-1 to the pathogenesis of diabetic retinopathy.

\section{Diabetic skin microangiopathy}

The pathogenesis of diabetic skin microangiopathy is complex (Figure 1). Functional diabetic microangiopathy is characterized by reduced microvascular reactivity and increased blood flow through arteriovenous shunts leading to an impaired nutritive capillary circulation, so-called capillary ischemia (Boulton et al 1982; Fagrell et al 1999; Tooke 2000). Impaired nutritive capillary circulation is especially pronounced in patients with peripheral arterial occlusive disease (Jörneskog et al 1995). A state of hypercoagulation and impaired fibrinolysis is also present in diabetic patients and may contribute to the deterioration of the skin microcirculation (Kalani et al 2007).

Recently, we have shown that $\mathrm{ET}_{\mathrm{A}}$ receptor blockade by BQ123 markedly increases the nutritive skin microcirculation

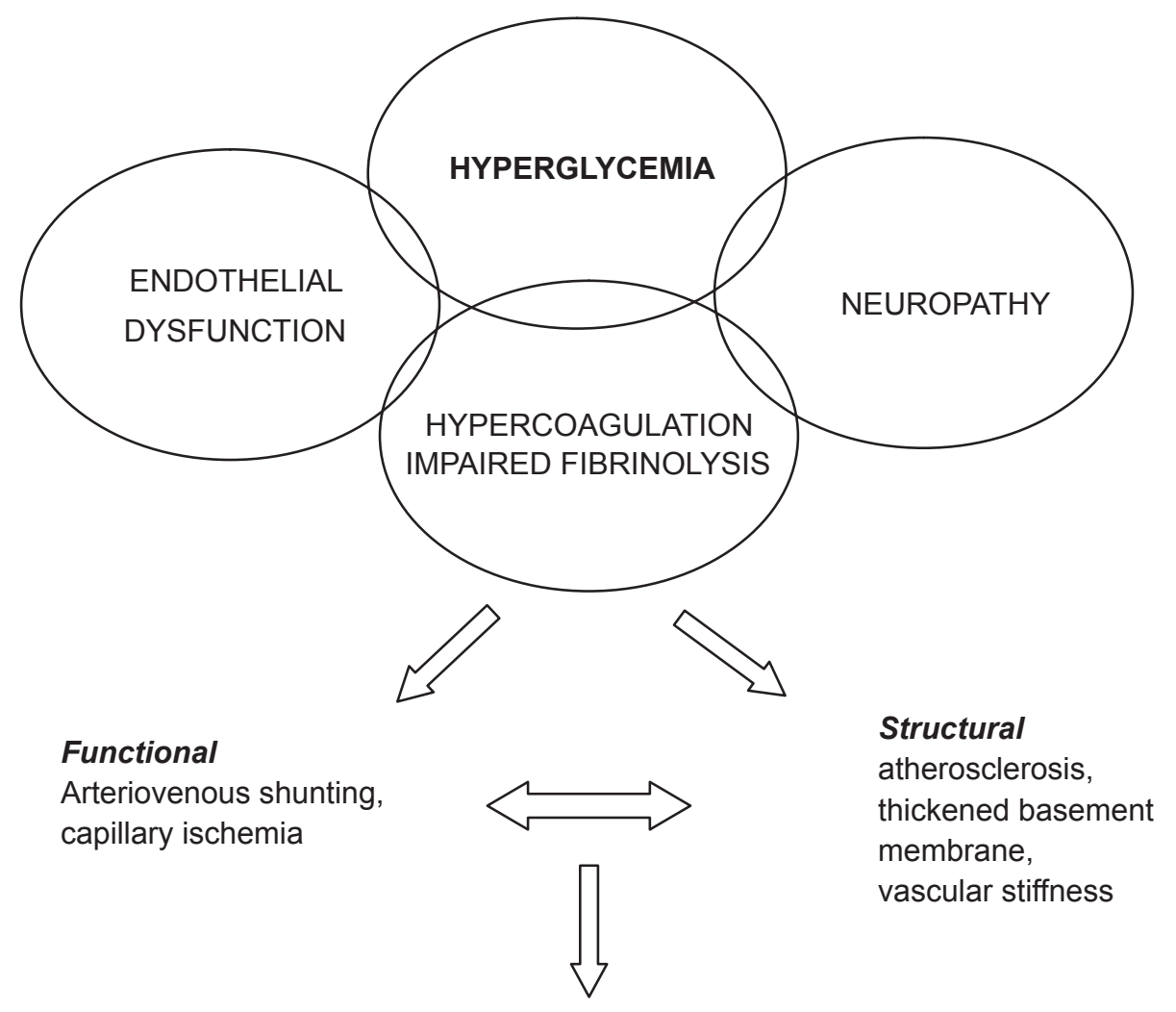

CLINICALLY MANIFEST COMPLICATIONS

Figure I Pathogenesis of diabetic skin microangiopathy. 
in patients with type 2 diabetes and microangiopathy (Settergren et al 2008). The results suggest that ET-1, through activation of the $\mathrm{ET}_{\mathrm{A}}$ receptor, is of importance for the regulation of the microcirculation in diabetic patients with microangiopathy. The skin nutritive microcirculation determined by nailfold capillary microscopy and the hyperemic response, ie, the peak value of the CBV following arterial occlusion, increased significantly during $\mathrm{ET}_{\mathrm{A}}$ receptor blockade, indicating improved microvascular reactivity (Figure $2 \mathrm{a}-\mathrm{b}$ ) (Settergren et al 2008). Interestingly, the increase in CBV during selective $\mathrm{ET}_{\mathrm{A}}$ receptor blockade was more pronounced in type 2 diabetic patients with a high body mass index (BMI) and low levels of insulin-like growth factor binding protein-1 (IGFBP-1), supporting the existence of a close relationship between insulin resistance and increased ET-1 activity. It is noteworthy that administration of the selective $\mathrm{ET}_{\mathrm{A}}$ receptor antagonist did not affect CBV in the nondiabetic control group. This supports the notion that the ET-1 system is upregulated in patients with type 2 diabetes and that $\mathrm{ET}_{\mathrm{A}}$ receptor blockade exerts hemodynamic effects only under such conditions.

Enhanced ET-1-mediated vasoconstriction of precapillary resistance vessels leads to impaired blood flow through nutritive capillaries and increased arteriovenous shunting in patients with type 2 diabetes. These patients are prone to arterial hypertension, partly due to vasoconstriction of precapillary resistance vessels, leading to an increased capillary blood pressure (Fegan et al 2003) due to disturbed autoregulation of capillary pressure as a consequence of insulin resistance. A reduction in capillary blood pressure, as a consequence of reduced arteriovenous shunt flow and an increased arteriovenous pressure difference, might increase the capillary blood circulation (Fegan et al 2003). The effects of selective $\mathrm{ET}_{\mathrm{A}}$ receptor blockade on the skin microcirculation may be a consequence of blocking the precapillary constrictor effects of ET-1 mediated by ET $_{\mathrm{A}}$ receptors. Furthermore, improvements in peak CBV reflect vasodilation at the precapillary level, indicating improved precapillary and capillary endothelial function.

Diabetic foot ulcers in the presence of peripheral arterial disease threatens both life and limb in these patients. However, the local nutritive skin microcirculation is severely deteriorated in diabetic patients with peripheral arterial occlusive disease and new treatments are urgently needed. We conducted a pilot study to investigate whether $\mathrm{ET}_{\mathrm{A}}$ receptor blockade improves peripheral tissue perfusion in diabetic patients with critical limb ischemia. During infusions of the selective $\mathrm{ET}_{\mathrm{A}}$ receptor blocker $\mathrm{BQ} 123$, transcutaneous oxygen tension $\left(\mathrm{TcPO}_{2}\right)$ at the dorsum of the foot and toe blood pressure (TBP) increased significantly (Figure 3a-b) (Kalani et al 2008). The increased local skin oxygenation during infusions of BQ123 suggests an improved nutritive capillary circulation. $\mathrm{TcPO}_{2}$ may partly reflect local nutritive capillary circulation and has been suggested for the evaluation of peripheral arterial disease and the prediction of ulcer outcomes (Kalani et al 1999). Increased TBP during $\mathrm{ET}_{\mathrm{A}}$ receptor blockade may be due to vasodilation of precapillary resistance vessels. The observed effect of $\mathrm{ET}_{\mathrm{A}}$ receptor blockade on peripheral tissue perfusion in these patients may be a consequence of blocking the precapillary constrictor effects of ET-1 mediated by $\mathrm{ET}_{\mathrm{A}}$ receptors. Furthermore, $\mathrm{ET}_{\mathrm{A}}$ receptor blockade has been shown to improve endothelium-dependent vasodilation by enhancing the bioavailability of nitric oxide, which appears to be of importance for microvascular function in diabetes (Mather et al 2002). In addition to the increased levels of ET-1 in patients with diabetes, as compared to nondiabetic controls (Settergren et al 2008), there are also indications of upregulation of ET receptors in diabetes (Khan et al 2003). The marked increase in peripheral blood flow observed following BQ123 infusion in the diabetic patients may therefore be related to
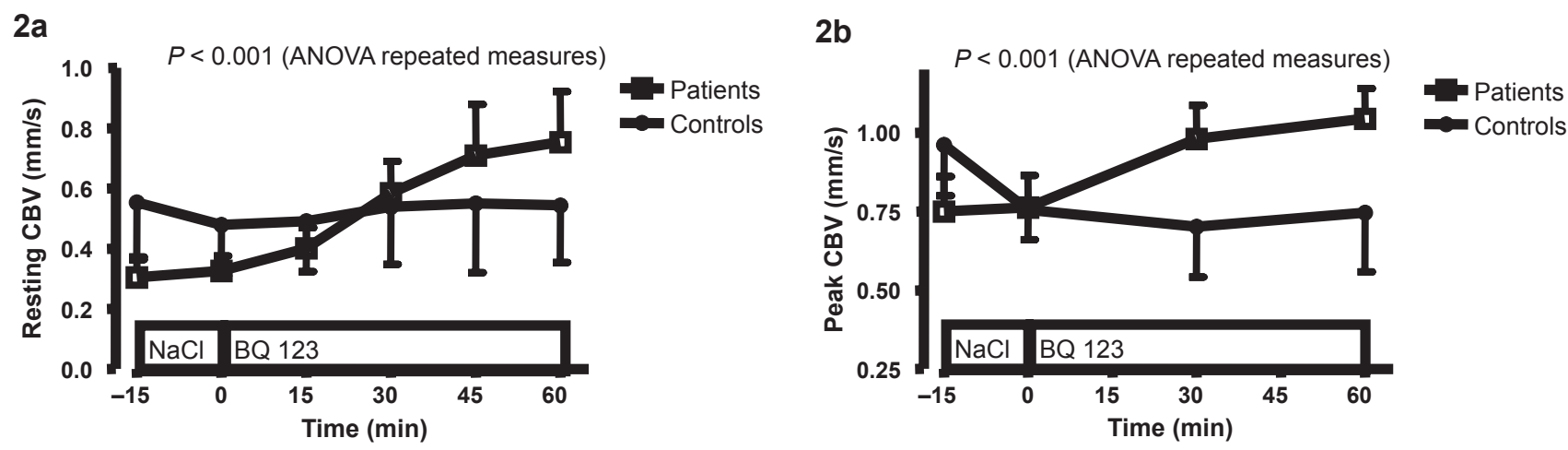

Figure 2 Effect of BQI 23 on resting capillary blood cell velocity (CBV) (a) and peak capillary blood cell velocity following a I-min arterial occlusion (b) in patients with type 2 diabetes $(n=10)$ and nondiabetic controls $(n=8)$. Data are shown as the mean and SEM.A significant difference between groups in the change in resting CBV and peak CBV, respectively, following a 60-min infusion of BQI23 is shown. Copyright (C) 2008. Reproduced with the kind permission of Karger AG, Basel from Settergren M, Pernow J, Brismar K, et al 2008. Endothelin-A receptor blockade improves nutritive skin capillary circulation in patients with type 2 diabetes and albuminuria.J Vasc Res, 45:295-302. 


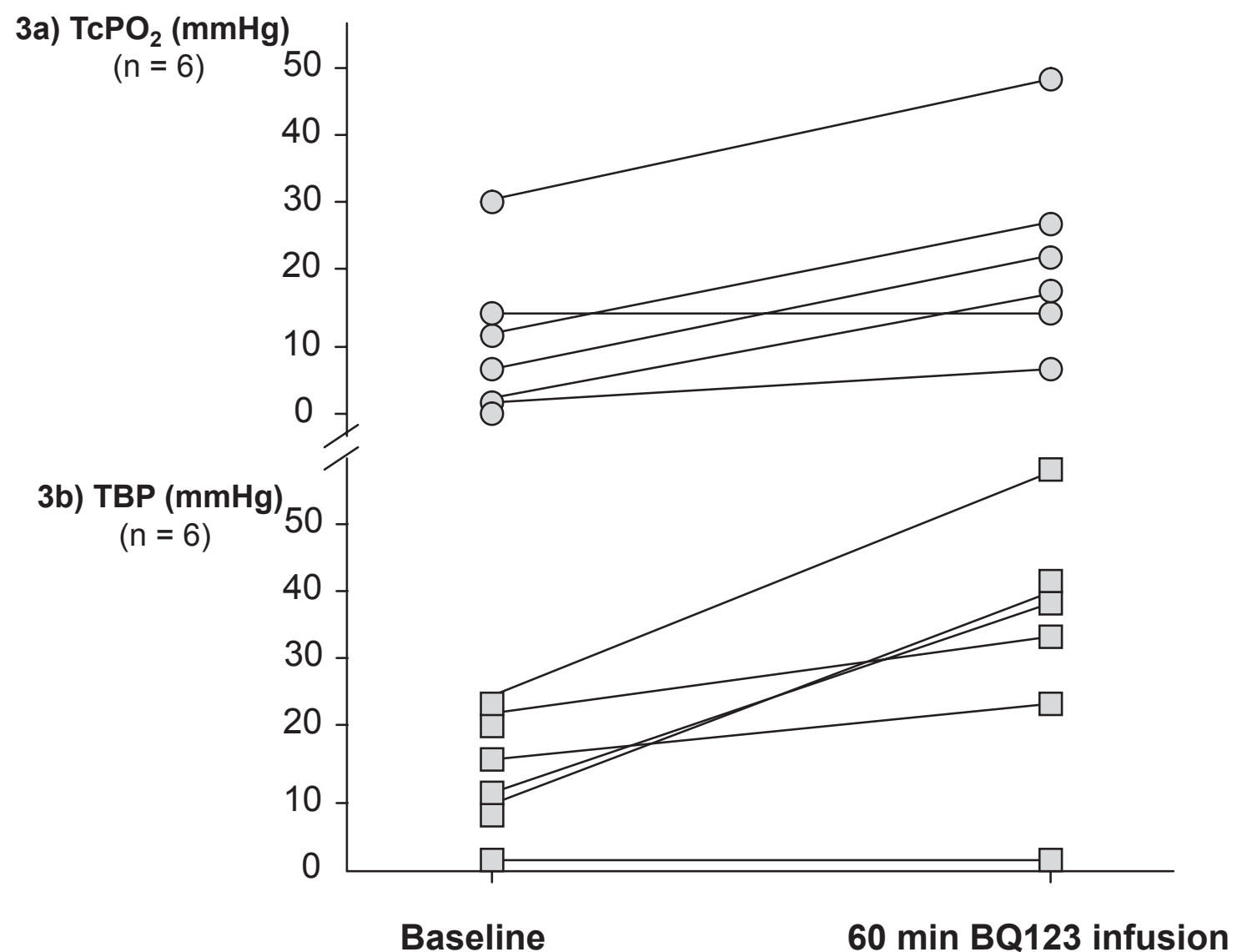

Figure 3 Effects of a 60-min infusion of a selective $\mathrm{ET}_{\mathrm{A}}$ receptor antagonist (BQ I 23) on transcutaneous oxygen tension ( TcPO $_{2}$ ) and toe blood pressure (TBP) in six patients with type 2 diabetes and critical limb ischemia.

increased production of ET-1 as well as an upregulation of $\mathrm{ET}_{\mathrm{A}}$ receptors mediating vasoconstriction.

\section{Conclusions}

Disturbed microvascular function in diabetes, ie, diabetic microangiopathy, plays an important role in the pathogenesis of specific complications in different organs. Impaired nutritive skin microcirculation has been demonstrated in both the diabetic hand and foot and might contribute to the development of such complications as sensorimotor neuropathy and nonhealing ulcers. ET-1 is a potent vasoconstrictor, proinflammatory, and mitogenic peptide produced by endothelial cells, VSMC, and inflammatory cells. The production and the plasma levels of ET-1 are elevated in patients with diabetes, and a positive correlation between plasma ET-1 levels and diabetic microangiopathy has been reported, suggesting a potential role of the endothelin system in the pathophysiology of vascular complications in diabetes. A large body of evidence from animal models and human studies indicates that ET-1 is causally involved in the pathogenesis of diabetic microangiopathy, but the potential of ET-1 blockers in the treatment of diabetic microangiopathy has not been investigated in human studies. Nevertheless, recent results from our studies in patients with diabetes indicate that targeting the ET-1 system might be of importance in the treatment of complications related to diabetic microangiopathy.

\section{Acknowledgments}

The author's own studies were supported by grants from the Swedish Research Council and the Stockholm County Council. Perimed AB, Stockholm, Sweden, supported the studies with the equipment used to measure the peripheral macro- and microcirculation. The author reports no conflicts of interest in this work.

\section{References}

Abassi ZA, Tate JE, Golomb E, et al. 1992. Role of neutral endopeptidase in the metabolism of endothelin. Hypertension, 20:89-95.

Ahlborg G, Lindström J. 2002. Insulin sensitivity and big ET-1 conversion to ET-1 after $\mathrm{ET}_{\mathrm{A}}$ - or $\mathrm{ET}_{\mathrm{B}}$-receptor blockade in humans. J Appl Physiol, 93:2112-21.

Ak G, Buyukberber S, Sevinc A, et al. 2001. The relation between plasma endothelin-1 levels and metabolic control, risk factors, treatment modalities, and diabetic microangiopathy in patients with type 2 diabetes mellitus. J Diabetes Complications, 15:150-7. 
Anfossi G, Russo I, Doronzo G, et al. 2007. Relevance of the vascular effects of insulin in the rationale of its therapeutical use. Cardiovasc Hematol Disord Drug Targets, 7:228-49.

Anggard E, Galton S, Rae G, et al. 1989. The fate of radioiodinated endothelin-1 and endothelin-3 in the rat. J Cardiovasc Pharmacol, 13:S46-S49.

Berti-Mattera LN, Gariepy CE, Burke RM, et al. 2006. Reduced expression of endothelin $\mathrm{B}$ receptors and mechanical hyperalgesia in experimental chronic diabetes. Exp Neurol, 201:399-406.

Boulton AJ, Scarpello JH, Ward JD. 1982. Venous oxygenation in the diabetic neuropathic foot: evidence of arteriovenous shunting? Diabetologia, 22:6-8.

Caballero AE, Arora S, Saouaf R, et al. 1999. Microvascular and macrovascular reactivity is reduced in subjects at risk for type 2 diabetes. Diabetes, 48:1856-62.

Cameron NE, Cotter MA, Low PA. 1991. Nerve blood flow in early experimental diabetes in rats: relation to conduction deficits. $\mathrm{Am} \mathrm{J}$ Physiol, 261:E1-E8.

Cameron NE, Cotter MA. 1995. Neurovascular dysfunction in diabetic rats. Potential contribution of autoxidation and free radicals examined using transition metal chelating agents. J Clin Invest, 96:1159-63.

Candido R, Allen TJ. 2002. Haemodynamics in microvascular complications in type 1 diabetes. Diabetes Metab Res Rev, 18:286-304.

Cardillo C, Kilcoyne CM, Cannon RO, et al. 2000. Increased activity of endogenous endothelin in patients with hypercholesterolemia. $J \mathrm{Am}$ Coll Cardiol, 36:1483-8.

Cardillo C, Kilcoyne CM, Waclawiw M, et al. 1999. Role of endothelin in the increased vascular tone of patients with essential hypertension. Hypertension, 33:753-8.

Chade AR, Krier JD, Textor SC, et al. 2006. Endothelin-A receptor blockade improves renal microvascular architecture and function in experimental hypercholesterolemia. J Am Soc Nephro, 17:3394-403.

Chakrabarti S, Gan XT, Merry A, et al. 1998. Augmented retinal endothelin-1, endothelin-3, endothelinA and endothelinB gene expression in chronic diabetes. Curr Eye Res, 17:301-7.

Chakrabarti S, Sima AA. 1997. Endothelin-1 and endothelin-3-like immunoreactivity in the eyes of diabetic and non-diabetic BB/W rats. Diabetes Res Clin Pract, 37:109-20.

Cooper ME. 1998. Pathogenesis, prevention, and treatment of diabetic nephropathy. Lancet, 352(9123):213-19.

Cowburn PJ, Cleland JG, McArthur JD, et al. 1999. Endothelin B receptors are functionally important in mediating vasoconstriction in the systemic circulation in patients with left ventricular systolic dysfunction. $J$ Am Coll Cardiol, 33:932-8.

Creager MA, Luscher TF, Cosentino F, et al. 2003. Diabetes and vascular disease: pathophysiology, clinical consequences, and medical therapy: Part I. Circulation, 108:1527-32.

De Mattia G, Cassone-Faldetta M, Bellini C, et al. 1998. Role of plasma and urinary endothelin-1 in early diabetic and hypertensive nephropathy. Am J Hypertens, 11:983-8.

Donatelli M, Colletti I, Bucalo ML, et al. 1994. Plasma endothelin levels in NIDDM patients with macroangiopathy. Diabetes Res, 25:159-64.

Fagrell B, Jorneskog G, Intaglietta M. 1999. Disturbed microvascular reactivity and shunting - a major cause for diabetic complications Vasc Med, 4:125-7.

Fegan PG, Tooke JE, Gooding KM, et al. 2003. Capillary pressure in subjects with type 2 diabetes and hypertension and the effect of antihypertensive therapy. Hypertension, 41:1111-17.

Gall MA, Rossing P, Skott P, et al. 1991. Prevalence of micro- and macroalbuminuria, arterial hypertension, retinopathy and large vessel disease in European type 2 (non-insulin-dependent) diabetic patients. Diabetologia, 34:655-61.

Giannini C, Dyck PJ, 1995. Basement membrane reduplication and pericyte degeneration precede development of diabetic polyneuropathy and are associated with its severity. Ann Neurol, 37:498-504.

Gokin AP, Fareed MU, Pan HL, et al. 2001. Local injection of endothelin-1 produces pain-like behaviour and excitation of nociceptors in rats. J Neurosci, 21:5358-66.
Groop PH, Forsblom C, Thomas MC, 2005. Mechanisms of disease: Pathway-selective insulin resistance and microvascular complications of diabetes. Nat Clin Pract Endocrinol Metab, 1:100-10.

Gundersen HJG. 1974. Peripheral blood flow and metabolic control in juvenile diabetes. Diabetologia, 10:225-31.

Halcox JP, Nour KR, Zalos G, et al. 2001. Coronary vasodilation and improvement in endothelial dysfunction with endothelin ET(A) receptor blockade. Circ Res, 89:969-76.

Jaap AJ, Hammersley MS, Shore AC, 1994. Reduced microvascular hyperaemia in subjects at risk of developing type 2 (non-insulin-dependent) diabetes mellitus. Diabetologia, 37:214-16.

Jansson P-A. 2007. Endothelial dysfunction in insulin resistance and type 2 diabetes. J Intern Med, 262:173-83.

Jarvis MF, Wessale JL, Zhu CZ, et al. 2000. ABT-627, an endothelin ET(A) receptor-selective antagonist, attenuates tactile allodynia in a diabetic rat model of neuropathic pain. Eur J Pharmacol, 388:29-35.

Jeffcoate WJ, Harding KG. 2003. Diabetic foot ulcers. Lancet, 361:1545-51.

Johnström P, Fryer TD, Richards HK, et al. 2005. Positron emission tomography using $18 \mathrm{~F}$-labelled endothelin- 1 reveals prevention of binding to cardiac receptors owing to tissue-specific clearance by ET B receptors in vivo. Br J Pharmacol, 144:115-22.

Jörneskog G, Brismar K, Fagrell B. 1995. Skin capillary circulation is more impaired in toes of diabetic than non-diabetic patients with peripheral vascular disease. Diabet Med, 12:36-41.

Jörneskog G, Brismar K, Fagrell B. 1998. Pronounced skin capillary ischemia in the feet of diabetic patients with bad metabolic control Diabetologia, 41:410-15.

Jörneskog G, Kalani M, Kuhl J, et al. 2005. Early microvascular dysfunction in healthy normal-weight males with heredity for type 2 diabetes. Diabetes Care, 28:1495-7.

Jörneskog G. 1995. Functional Microangiopathy in the Digital Skin of Patients with Diabetes Mellitus [dissertation]. Stockholm, Sweden: Karolinska Institute.

Kalani M, Brismar K, Fagrell B, et al. 1999. Transcutaneous oxygen tension and toe blood pressure as predictors for outcome of diabetic foot ulcers. Diabetes Care, 22:147-51.

Kalani M, Pernow J, Bragd J, et al. 2008. Improved peripheral perfusion during endothelin-A receptor blockade in patients with type 2 diabetes and critical limb ischemia. Diabetes Care, 31:e56.

Kalani M, Silveira A, Blombäck M, et al. 2007. Beneficial effects of dalteparin on haemostatic function and local tissue oxygenation in patients with diabetes, severe vascular disease and foot ulcers. Thromb Res, 120:653-61.

Khan ZA, Chakrabarti S. 2003. Endothelins in chronic diabetic complications. Can J Physiol Pharmacol, 81:622-34.

King H, Aubert RE, Herman WH. 1998. Global burden of diabetes 1995-2025: prevalence, numerical estimates and projections. Diabetes Care, 21:1414-31.

Kohan DE. 1997. Endothelins in the normal and diseased kidney. Am $J$ Kidney Dis, 29:2-26.

Kohner EM, Patel V, Rassam SM. 1995. Role of blood flow and impaired autoregulation in the pathogenesis of diabetic retinopathy. Diabetes, 44:603-7.

Kyriakides ZS, Kremastinos DT, Bofilis E, et al. 2000. Endogenous endothelin maintains coronary artery tone by endothelin type A receptor stimulation in patients undergoing coronary arteriography. Heart, 84:176-82.

Lee YJ, Shin SJ, Tsai JH. 1994. Increased urinary endothelin-1-like immunoreactivity in NIDDM patients with albuminuria. Diabetes Care, 17:263-6.

Li L, Fink GD, Watts SW, et al. 2003. Endothelin-1 increases vascular superoxide via endothelin(A)-NADPH oxidase pathway in low-renin hypertension. Circulation, 107:1053-8.

Love MP, Ferro CJ, Haynes WG, et al. 2000. Endothelin receptor antagonism in patients with chronic heart failure. Cardiovasc Res, 47:166-72.

Low PA, Lagerlund TD, McManis PG. 1989. Nerve blood flow and oxygen delivery in normal, diabetic, and ischemic neuropathy. Int Rev Neurobiol, 31:355-438. 
Luscher TF, Creager MA, Beckman JA, et al. 2003. Diabetes and vascular disease: pathophysiology, clinical consequences, and medical therapy: Part II. Circulation, 108:1655-61.

Masuzawa K, Jesmin S, Maeda S, et al. 2006. Effect of endothelin dual receptor antagonist on VEGF levels in streptozotocin-induced diabetic rat retina. Exp Biol Med, 231:1090-4.

Mather KJ, Mirzamohammadi B, Lteif A, et al. 2002. Endothelin contributes to basal vascular tone and endothelial dysfunction in human obesity and type 2 diabetes. Diabetes, 51:3517-23.

Molenaar P, O’Reilly G, Sharkey A, et al. 1993. Characterization and localization of endothelin receptor subtypes in the human atrioventricular conducting system and myocardium. Circ Res, 72:526-38.

Nohria A, Garrett L, Johnson W, et al. 2003. Endothelin-1 and vascular tone in subjects with atherogenic risk factors. Hypertension, 42:43-8.

Pang IH, Yorio T. 1997. Ocular actions of endothelins. Proc Soc Exp Biol Med, 215:21-34.

Pernow J, Bohm F, Johansson BL, et al. 2000. Enhanced vasoconstrictor response to endothelin-B-receptor stimulation in patients with atherosclerosis. J Cardiovasc Pharmacol, 36:S418-S20.

Properzi G, Terenghi G, Gu XH, et al. 1995. Early increase precedes a depletion of endothelin-1 but not of von Willebrand factor in cutaneous microvessels of diabetic patients; a quantitative immunohistochemical study. J Pathol, 175:243-52.

Rask-Madsen C, King GL, 2007. Mechanisms of disease: endothelial dysfunction in insulin resistance and diabetes. Nat Clin Pract Endocrinol Metab, 3:46-56.

Rayman G, Williams SA, Spencer PD, et al. 1986. Impaired microvascular hyperaemic response to minor skin trauma in type 1 diabetes. $\mathrm{Br} \mathrm{Med} J$, 292:1295-8.

Resink TJ, Hahn AWA, Scott-Burden T, et al. 1990. Inducible endothelin messenger RNA expression and peptide secretion in cultured human vascular smooth muscle cells. Biochem Biophys Res Commun, 168:1303-10

Romero M, Jiménez R, Sánchez M, et al. 2008. Quercetin inhibits vascular superoxide production induced by endothelin-1: Role of NADPH oxidase, uncoupled eNOS and PKC. Atherosclerosis, Mar 16 [Epub ahead of print].

Sakurai T, Yanagisawa M, Masaki T. 1992. Molecular characterization of endothelin receptors. Trends Pharmacol Sci, 13:103-8.

Sandeman DD, Pym CA, Green EM, et al. 1991. Microvascular vasodilatation in feet of newly diagnosed non-insulin dependent diabetic patients. Br Med J, 302:1122-3.

Sasser JM, Sullivan JC, Hobbs JL, et al. 2007. Endothelin A receptor blockade reduces diabetic renal injury via an anti-inflammatory mechanism. J Am Soc Nephrol, 18:143-54.

Seo B, Oemar BS, Siebenmann R, et al. 1994. Both ETA and ETB receptors mediate contraction to endothelin-1 in human blood vessels. Circulation, 89:1203-8.

Settergren M, Pernow J, Brismar K, et al. 2008. Endothelin-A receptor blockade improves nutritive skin capillary circulation in patients with type 2 diabetes and albuminuria. J Vasc Res, 45:295-302.
Shore AC, Jaap AJ, Tooke JE. 1994. Capillary pressure in patients with NIDDM. Diabetes, 43:1198-202.

Siren AL, Lewczuk P, Hasselblatt M, et al. 2002. Endothelin B receptor deficiency augments neuronal damage upon exposure to hypoxiaischemia in vivo. Brain Res, 945:144-9.

Strachan FE, Spratt JC, Wilkinson IB, et al. 1999. Systemic blockade of the endothelin-B receptor increases peripheral vascular resistance in healthy men. Hypertension, 33:581-5.

Takahashi K, Ghatei MA, Lam HC, et al. 1990. Elevated plasma endothelin in patients with diabetes mellitus. Diabetologia, 33:306-10.

Thrainsdottir S, Malik RA, Dahlin LB, et al. 2003. Endoneurial capillary abnormalities presage deterioration of glucose tolerance and accompany peripheral neuropathy in man. Diabetes, 52:2615-22.

Tooke JE, Hanneman MM. 2000. Adverse endothelial function and the insulin resistance syndrome. $J$ Int Med, 247:425-31.

Tooke JE. 1983. Capillary pressure in non-insulin-dependent diabetes. Int Angiol, 2:167-71.

Tooke JE. 1983. Microvascular haemodynamics in diabetes mellitus. Clin Sci, 70:119-25.

Tooke JE. 1995. Microvascular function in human diabetes. A physiological perspective. Diabetes, 44:721-6.

Tooke JE. 2000. Possible pathophysiological mechanisms for diabetic angiopathy in type 2 diabetes. J Diabetes Complications, 14:197-200.

Tur E, Yosipovitch, Bar-On Y. 1991. Skin reactive hyperaemia in diabetic patients. A study by laser Doppler flowmetry. Diabetes Care, 14:958-62.

Tymms DJ, Tooke JE. 1988. The effect of continuous subcutaneous insulin infusion (CSII) on microvascular blood flow in diabetes mellitus. Int $J$ Microcirc Clin Exp, 7:347-56.

Verhaar MC, Strachan FE, Newby DE, et al. 1998. Endothelin-A receptor antagonist-mediated vasodilatation is attenuated by inhibition of nitric oxide synthesis and by endothelin-B receptor blockade. Circulation, 97:752-6.

Walmsley D, Wales JK, Wiles PG. 1989. Reduced hyperaemia following skin trauma: evidence for an impaired microvascular response to injury in the diabetic foot. Diabetologia, 32:736-9.

Wedgwood S, McMullan DM, Bekker JM, et al. 2001. Role for endothelin-1induced superoxide and peroxynitrite production in rebound pulmonary hypertension associated with inhaled nitric oxide therapy. Circ Res, 89:357-64.

Yanagisawa M, Kurihara H, Kimura S, et al. 1988. A novel potent vasoconstrictor peptide produced by vascular endothelial cells. Nature, 332:411-15.

Zanatta CM, Gerchman F, Burttet L, et al. 2008. Endothelin-1 levels and albuminuria in patients with type 2 diabetes mellitus. Diab Res Clin Pract, 80:299-304. 